\title{
IMPROVING STUDENTS SPEAKING SKILLS BY RECOUNT TEXT
}

\author{
JuitaMariani Simamora ${ }^{1}$ \\ Universitas Prima Indonesia \\ Ramauli Sinaga ${ }^{2}$ \\ Universitas Prima Indonesia \\ Sri NintaTarigan ${ }^{3}$ \\ Universitas Prima Indonesia \\ Juitamaryani1997@gmail.com ${ }^{1}$
}

Submit, 30-11-2019 Accepted, 30-12-2019 Publish, 30-12-2019

\begin{abstract}
The aim of this study was to find out whether there was a student ability to speaking after learning recount text. This type of research is quantitative. The data used is the value of students in knowing improvement in speaking students to understanding recount text. Data collection techniques in this study were interviews as introductory stage with students and teacher to find out the improvement in students speaking skills, observation, questionnaire and data collection. The conclusion of this research is that after doing cycle 1 and cycle 2 the recount text can to improve students ability
\end{abstract}

Key words: speaking skills, recount text.

\section{INTRODUCTION}

In high school must a better understanding of speaking English because since school students learned English. However, according to researcher at SMA GKPI students speaking is low. So, researcher do learning method that can improve students speaking skill by recount text. The researcher can to conclude that recount text to improve speaking skills because researcher encourage students to learn and provide a text about holidays so that students understand. The researcher examines students speaking skills by having students speak in front of the class one by one. That way, students become more confident to expressing their friends. The cycle conducted by the researcher is able to improve students speaking skills with value obtained by students.

English is an international language used by countries in the world. In learning English, there are four skills that need to know by students. They are listening, speaking, reading and writing. Language is a system of conventional 
spoken and written symbols by human as members of a social group for interaction. Language function is to communicate to the expression of identity and emotional release

Speaking skills is important for students to be learned capability and their understanding, how to send idea and how to spell the word well. In this case, the students' motivation and interest are very needed to make the process for their understanding more easily. Speaking skills for students still considered difficult to teach for students because should trained, habituated and lack of vocabulary. Story telling is a spoken activity for someone to speak to each others with the purpose to deliver messagess or to amuse a listener ( reader ).

Tarigan, \& Guntur, H. (2005) states that "speaking is a skill of conveying words or sounds of articulation to express or to deliver ideas, opinions, or felling. Despite its importance, for many years, teaching speaking has been undervalued and english language teachers have continued to teach speaking just as a repetition of drills or memorization of dialogues. However, today's world requires that the goal of teaching speaking should improve students communicative circumstance. To most people, mastering the art of speaking is the single most important aspect of learning a second or foreign language, and success is measured in terms of the ability to carry out a conversation in the language."

From all the previous research on improving students speaking skills mentioned previously, a study conducted by Kurnia (2015) improvement of the spoken recount text. Another study on the other side, Junggle sentences can improve the students writing skills. So, it is important to learn concrete evidence from students speaking activities that recount text can improve students speaking skills by recount text. In this way, students speaking skills can be investigated by recount text. Therefore this researcher, tries to delve deeper into whether recount text can improve students speaking skills by retelling events in the past in front of the class.

\section{LITERATUR REVIEW}

Teaching and learning process will be more interesting when the teacher applies a method or technique which can evoke atmosphere in the classroom.Research in this area was conducted by Isnaini (2011). in the study, she suggested teachers to use Round robin structure to help them teaching attractively and to give their students opportunity to produce sentences for performing their speaking. The analysis of her study showed that the speaking achievement of the students improved and the average score of the students was higher than minimal score that had been determined by the school. 
Another research was conducted by Utami (2013) the goal in this studywas to know the application of story board game as teaching media in improvingstudents speaking ability and studentsachievement in speaking English afterbeing taught by this game. The result of her study showed that the achievement ofstudents in speaking increased, but there were still some aspects like stress andintonation did not significantly increase.

The last, Chen and I-Jung (2005) state that game offer students fun filled and relaxing learning atmosphere. In teaching and learning process it can bedenied that relaxing and enjoyable situation of the class plays important rule.

Teaching speaking is challenging for a teacher. Beside speaking is not easy to be learned by students, not all students have the same interest. Based on the previous study, teachers should be more creative in managing the best way to help them. Teachers have to vary their technique of teaching to gain the students interest and motivation in speaking. There are so many techniques that can beused for teaching speaking, such as cooperative learning or also can used digitalmedia. In this study the researcher uses Recount Text for teaching speaking in High School.

\section{RESEARCH METHOD}

This is a quantitative research. The study used quantitative approach. The method of the study is storytelling method about recount text. This study focuses on telling students about experience students. In this application, the researcher asked the students to share or retell their memories or experiences that have been experienced. The application of this method begins with the teacher exemplifying an interesting story, then asks middle school students who are interested in sharing their experiences going forward to the class to tell stories. In this method, the assessment is focused on how students are able to recite words, expressions and intonation and clarity of His storyline.

This research was conducted at SMA GKPI Padang Bulan as the location of the study last month and was conducted in August 2019. This type of research is classroom action research, focusing on check the actions taken to improve students's speaking skills and student learning outcomes in English.The subjects of this research are the students on the X grade in academic year of 2019/2020. There were one class X.IIS that consists32 students taken as the subject of research.

The data of this research was obtained through several techniques, such as interviews, observations, test, questionnaires and documentation.Procedures and steps in carrying out actions follow the LEWIN KURT model which includes 4 steps, namely planning, action, observation and reflection. Sources of data were collected and studied in a data source study that included VIII grade of document 
data. The method used is the method of interview, observation, test and documentation. The instruments used in the study were observation sheets, indicators of achievement of speaking skills, interview sheets, test questions, and plans for applying learning. The procedures of the data collection techniques are presented below:

1. Interview. The researcher conducted an interview to get information on the teaching and learning process. for that, researchers interviewed English teachers and students. The researcher interviewed the English Language Teacher related to the teaching and learning process and the problems faced. In addition, researchers interviewed students to find out about student opinions and student difficulties during the teaching and learning process of speaking. Then, interviews were conducted with reflection steps from each research cycle. students are directed to reflect the results of the action. Interviews aims to get opinions and suggestions from English Language Teachers and Students.

2. Observation. To gather information about the teaching and learning process, researchers conducted classroom observations. The observation sheet is used to collect data. The researcher marks the activities that have been carried out. This technique is carried out in surveillance and also during the actions and steps of the research observation.

3. Test. Speaking tests were also done to obtain the information about the student's speaking skills before and after the implementation of Recount Text in the teaching and learning process of speaking. The tests were done twice in the forms of pre-test and post-test. The researcher used speaking rubrics to collect the scores of the student's speaking performances. Furthermore, the results were used to see whether there were improvements after the actions or not.

4. Questionnaires. In this technique, the researcher distributed questionnaires to the student's to get the supportive data about their opinions toward their interests, feelings, responses about the teaching and learning process and the implementation of the text and their abilities in speaking English as well. The questionnaires were distributed in the reflection step of each cycles.

5. Documentation. Researcher also use additional instruments to support research to get more complete data. to document the teaching and learning process researchers used a photo-video camera in surveillance, action and observation of data research steps in the form of photos and videos.

\section{FINDING}

\section{Cycle One}

Cycle one consisted of two meetings. The research was conducted on September 28 and October 26, 2019. At the first meeting, the researcher examined 
the attendance list of class $\mathrm{X}$ students, the researcher told students about how to handle the class for the meeting. The researcher explains how to tell about past experiences. The researcher used the storytelling method with Recount Text. The researcher explains what Recount Text is, what the purpose is, whatever Generic Structure of Recount Text and Language Features of Recount Text then provide examples of recount text to be discussed together.

The researcher explained that :

1. Defenition of Recount Text is a text which retells event or experiences in the past.

2. The purpose of Recount Text is to entertain or to inform the Reader or Listener.

3. Generic Structure of Recount Text; a) orientation: introducing the participants, place and time such as who was in volved, where it happened and when it happened, b) events: describing series of events that happened in the past, c) re-orientation: conclusion

4. Language Features; a) introducing personal participants ( I, My Family, My friend, etc), b) simple past tense ( $V+V 2), c)$ using chronological events, d) conjuctions (first, and, then, finally, after that, etc), e) linking verbs ( was, were), f) action Verb ( went, stayed)

5. Example of Recount Text with the title is A TRIP TO PARAPAT. Last Friday was public holiday. The students of SMA GKPI PAMEN took a trip to Parapat. They hired three buses. They were new and luxurious. In the morning the students woke up early. Their mother prepared some food, drinks, and fruits for them. Their parents took them to the school. These buses were already there. Some students were in buses. Their parents were waiting on both sides of street. At six o'clock the buses left their school. The students looked very happy and started to sing.

At nine o'clock they reached Parapat. The students hurriedly got out of the buses and carried their things and food. They gathered under a big tree. After they took a rest, they had their meals.At about ten o'clock some of the students changed into their swim suits and ran into about for a soil. At three o'clock the teachers called the students together because it was time to go home. In summary, the trip was very enjoyable. This place is so impressive with its beautiful panorama and boat ride.

\section{A TRIP TO PARAPAT}

Orientation:

Last Friday was public holiday. The students of SMA GKPI PAMEN took a trip to Parapat. They hired three buses. They were new and luxurious. 


\section{Event 1:}

Their mother prepared some food, drinks, and fruits for them. Their parents took them to the school. These buses were already there. Some students were in buses. Their parents were waiting on both sides of street. At six o'clock the buses left their school. The students looked very happy and started to sing.

\section{Event 2:}

At nine o'clock they reached Parapat. The students hurriedly got out of the buses and carried their things and food. They gathered under a big tree. After they took a rest, they had their meals.

\section{Event 3:}

In summary, the trip was very enjoyable. This place is so impressive with its beautiful panorama and boat ride.

The researcher read the Recount Text example and to invite students to read the text together to observation and to know the pronunciation of class Xstudents.the pronunciation of students in reading the text is not good. Students are embarrassed to ask especially to speaking. Therefore, the researcher instructs students to advance one by one in front of the class to read the text as training students speaking skills. After that, students translate the Recount Text to Indonesian so that students understand. Then, students look for the generic structure of Recount Text.

After the researcher explained everything, the researcher give the text to the student with the title "ATrip To Parapat " and explained it. After that for 5 minutes the students discussed the text and retell it again in front of the class. Students' responses to the method are very rushed and the language in the text is a new language so it is not easy to understand. Plus the students' vocabulary is lacking. When speaking in front of the class students feel nervous and there are also noisy students when their friends speak in front of the class.

The initial stage of the Researcher made observations in grade X.IIS GKPI PAMEN. The average student learning outcomes were 68. Based on the data taken from English Teacher class X SMA SWASTA GKPI Padang Bulan states that the learning value of students is not yet complete KKM (75). Student's speaking skills are still low. 
Table 1.Here The Scores of Students Learning Outcomes in The Class by The English Teacher :

\begin{tabular}{|c|c|c|c|c|c|}
\hline Number & Name & $\begin{array}{l}\text { Ideal } \\
\text { Score }\end{array}$ & $\begin{array}{l}\text { KKM } \\
\text { Score }\end{array}$ & $\%$ & Information \\
\hline & & & Students & Absorption & \\
\hline 1 & AS & 100 & 75 & 75 & B \\
\hline 2 & AS & 100 & 75 & 70 & $\mathrm{C}$ \\
\hline 3 & AP & 100 & 75 & 75 & $\mathrm{~B}$ \\
\hline 4 & $\mathrm{AG}$ & 100 & 75 & 70 & $\mathrm{C}$ \\
\hline 5 & $\mathrm{AL}$ & 100 & 75 & 75 & $\mathrm{~B}$ \\
\hline 6 & $\mathrm{BG}$ & 100 & 75 & 70 & $\mathrm{C}$ \\
\hline 7 & $\mathrm{BS}$ & 100 & 75 & 80 & B \\
\hline 8 & $\mathrm{BT}$ & 100 & 75 & 75 & B \\
\hline 9 & $\mathrm{BC}$ & 100 & 75 & 75 & $\mathrm{~B}$ \\
\hline 10 & $\mathrm{CS}$ & 100 & 75 & 75 & $\mathrm{~B}$ \\
\hline 11 & $\mathrm{CA}$ & 100 & 75 & 80 & B \\
\hline 12 & DS & 100 & 75 & 75 & B \\
\hline 13 & DG & 100 & 75 & 80 & B \\
\hline 14 & DP & 100 & 75 & 70 & $\mathrm{C}$ \\
\hline 15 & EK & 100 & 75 & 70 & $\mathrm{C}$ \\
\hline 16 & ED & 100 & 75 & 70 & $\mathrm{C}$ \\
\hline 17 & $\mathrm{ES}$ & 100 & 75 & 75 & B \\
\hline 18 & EN & 100 & 75 & 75 & B \\
\hline 19 & $\mathrm{ES}$ & 100 & 75 & 80 & B \\
\hline 20 & FS & 100 & 75 & 80 & B \\
\hline 21 & $\mathrm{FP}$ & 100 & 75 & 80 & $\mathrm{~B}$ \\
\hline 22 & $\mathrm{MN}$ & 100 & 75 & 75 & $\mathrm{~B}$ \\
\hline 23 & MM & 100 & 75 & 75 & $\mathrm{~B}$ \\
\hline 24 & MP & 100 & 75 & 80 & B \\
\hline 25 & MS & 100 & 75 & 80 & B \\
\hline 26 & $\mathrm{RD}$ & 100 & 75 & 80 & B \\
\hline 27 & SS & 100 & 75 & 80 & $\mathrm{~B}$ \\
\hline 28 & $\mathrm{SG}$ & 100 & 75 & 70 & $\mathrm{C}$ \\
\hline 29 & SM & 100 & 75 & 85 & $\mathrm{~A}$ \\
\hline 30 & SP & 100 & 75 & 70 & $\mathrm{C}$ \\
\hline 31 & VB & 100 & 75 & 70 & $\mathrm{C}$ \\
\hline 32 & WS & 100 & 75 & 70 & $\mathrm{C}$ \\
\hline Total & & 3200 & & 2410 & \\
\hline Average & & $100 \%$ & & 75,31 & \\
\hline
\end{tabular}

The results obtained not yet reached theg predetermined indicators. So that, at the stage this is said to be unsuccessful so it needs to do levels in cycles I and II use improve the speaking skills of class X students GKPI Padang Bulan. After completed the implementation of learning activities in cycle I actions with 
the use of storytelling method by Recount Text.Next giving a test to find out students learning outcomes tests. What is given is telling stories in front of the class. The results of the first cycle test analysis can be seen as following :

Table 2.Cycle I Students Score Learning Outcomes

\begin{tabular}{|c|c|c|c|c|c|}
\hline Number & Name & $\begin{array}{l}\text { Ideal } \\
\text { Score }\end{array}$ & $\begin{array}{l}\text { KKM } \\
\text { Score }\end{array}$ & $\%$ & Information \\
\hline & & & Students & Absorption & \\
\hline 1 & AS & 100 & 75 & 75 & B \\
\hline 2 & AS & 100 & 75 & 75 & $\mathrm{~B}$ \\
\hline 3 & AP & 100 & 75 & 75 & B \\
\hline 4 & $\mathrm{AG}$ & 100 & 75 & 75 & B \\
\hline 5 & $\mathrm{AL}$ & 100 & 75 & 75 & B \\
\hline 6 & $\mathrm{BG}$ & 100 & 75 & 75 & B \\
\hline 7 & $\mathrm{BS}$ & 100 & 75 & 80 & B \\
\hline 8 & BT & 100 & 75 & 75 & B \\
\hline 9 & $\mathrm{BC}$ & 100 & 75 & 75 & B \\
\hline 10 & $\mathrm{CS}$ & 100 & 75 & 75 & B \\
\hline 11 & $\mathrm{CA}$ & 100 & 75 & 80 & B \\
\hline 12 & $\mathrm{DS}$ & 100 & 75 & 75 & B \\
\hline 13 & DG & 100 & 75 & 80 & B \\
\hline 14 & DP & 100 & 75 & 70 & $\mathrm{C}$ \\
\hline 15 & EK & 100 & 75 & 75 & B \\
\hline 16 & ED & 100 & 75 & 70 & $\mathrm{C}$ \\
\hline 17 & ES & 100 & 75 & 75 & B \\
\hline 18 & EN & 100 & 75 & 75 & $\mathrm{~B}$ \\
\hline 19 & $\mathrm{ES}$ & 100 & 75 & 80 & $\mathrm{~B}$ \\
\hline 20 & FS & 100 & 75 & 80 & B \\
\hline 21 & FP & 100 & 75 & 80 & B \\
\hline 22 & $\mathrm{MN}$ & 100 & 75 & 75 & B \\
\hline 23 & $\mathrm{MM}$ & 100 & 75 & 75 & B \\
\hline 24 & MP & 100 & 75 & 80 & B \\
\hline 25 & MS & 100 & 75 & 80 & $\mathrm{~B}$ \\
\hline 26 & $\mathrm{RD}$ & 100 & 75 & 80 & $\mathrm{~B}$ \\
\hline 27 & SS & 100 & 75 & 80 & B \\
\hline 28 & $\mathrm{SG}$ & 100 & 75 & 70 & $\mathrm{C}$ \\
\hline 29 & SM & 100 & 75 & 85 & A \\
\hline 30 & SP & 100 & 75 & 70 & $\mathrm{C}$ \\
\hline 31 & VB & 100 & 75 & 70 & $\mathrm{C}$ \\
\hline 32 & WS & 100 & 75 & 70 & $\mathrm{C}$ \\
\hline Total & & 3200 & & 2430 & \\
\hline Average & & $100 \%$ & & 75,93 & \\
\hline
\end{tabular}


Based on the analysis above. The average score has shown an increase in the results test classical learning before the research value of 68 . After conducting research that is equal 75, it had not reached KKM determined by the school is equal to 75 , while the percentage of absorption of individual students 75 has reached the set target. Based on observations students activity in the first cycle and test the results of the action of the first cycle then carried out an evaluation cycle I evaluation is used as a reference for planning more effective actions for better learning outcomes in cycle II. Basically the implementation of the second cycle is not much different frpm the implementation of the first cycle. Only a few things that are considered lacking in the first cycle are corrected in cycle II and adjusted with changes to be achieved. The results obtained in this cycle are collected as well analyzed. The following is the presentation of the learning outcomes of class X students GKPI Padang Bulan Medan.

Table 3.Cycle II Students Score Learning Outcomes

\begin{tabular}{|c|c|c|c|c|c|}
\hline Number & Name & $\begin{array}{l}\text { Ideal } \\
\text { Score }\end{array}$ & $\begin{array}{l}\text { KKM } \\
\text { Score }\end{array}$ & $\%$ & Information \\
\hline & & & Students & Absorption & \\
\hline 1 & AS & 100 & 75 & 75 & B \\
\hline 2 & AS & 100 & 75 & 75 & B \\
\hline 3 & AP & 100 & 75 & 75 & B \\
\hline 4 & $\mathrm{AG}$ & 100 & 75 & 75 & B \\
\hline 5 & $\mathrm{AL}$ & 100 & 75 & 75 & B \\
\hline 6 & $\mathrm{BG}$ & 100 & 75 & 75 & B \\
\hline 7 & BS & 100 & 75 & 85 & A \\
\hline 8 & BT & 100 & 75 & 75 & B \\
\hline 9 & $\mathrm{BC}$ & 100 & 75 & 75 & $\mathrm{~B}$ \\
\hline 10 & $\mathrm{CS}$ & 100 & 75 & 75 & B \\
\hline 11 & $\mathrm{CA}$ & 100 & 75 & 80 & B \\
\hline 12 & DS & 100 & 75 & 75 & B \\
\hline 13 & DG & 100 & 75 & 80 & B \\
\hline 14 & DP & 100 & 75 & 75 & B \\
\hline 15 & EK & 100 & 75 & 75 & B \\
\hline 16 & ED & 100 & 75 & 75 & B \\
\hline 17 & ES & 100 & 75 & 75 & B \\
\hline 18 & EN & 100 & 75 & 75 & B \\
\hline 19 & $\mathrm{ES}$ & 100 & 75 & 80 & B \\
\hline 20 & FS & 100 & 75 & 80 & $\mathrm{~B}$ \\
\hline 21 & FP & 100 & 75 & 80 & $\mathrm{~B}$ \\
\hline 22 & $\mathrm{MN}$ & 100 & 75 & 75 & $\mathrm{~B}$ \\
\hline 23 & MM & 100 & 75 & 75 & B \\
\hline 24 & MP & 100 & 75 & 80 & B \\
\hline
\end{tabular}




\begin{tabular}{cccccc}
\hline 25 & MS & 100 & 75 & 80 & B \\
\hline 26 & RD & 100 & 75 & 80 & B \\
\hline 27 & SS & 100 & 75 & 80 & B \\
\hline 28 & SG & 100 & 75 & 75 & B \\
\hline 29 & SM & 100 & 75 & 85 & A \\
\hline 30 & SP & 100 & 75 & 75 & B \\
\hline 31 & VB & 100 & 75 & 75 & B \\
\hline 32 & WS & 100 & 75 & 70 & C \\
\hline Total & & 3200 & & 2460 & \\
\hline Average & & $100 \%$ & & 76,87 & \\
\hline
\end{tabular}

Based on the results of the implementation of the second cycle can be seen students motivation in activities learning is very good and students are more active in learning to speak in class. That matter indicated an increase in the percentage of acquisition from cycle I to cycle II which is an average value of 75 at the first cycle becomes an average value of 75 in cycle II. The ability of class X students GKPI Padang Bulan Medan can be said to increase in the second cycle because it has reached KKM. Only one student does not reach KKM because student prefer to play alone and fantasize.

\section{DISCUSSION}

From the observation of many students who are actively learning English. Students are more enthusiastic about asking unknown things. But, there are also students who lack initiative in study. Student interest in high learning. Thus students are attracted to following the recount text learning.

English learning outcomes in cycle II can be known after the second daily test was held. To find out the results of language learning English in cycle II, the researcher a documentation study on list of the second daily test values on learning cycle II.

There were two previous researchers to support the data. First, Malinda (2017). The conclusion of her research was Junggle sentence can improve the students writing skill. Second, Kurnia (2015). The conclusion of her research was fishbowl technique on the spoken recount skill.

Thus,the researcher concluded application of the method of telling stories increases the ability to speak students of GKPI Padang Bulan Medan state shoe good results and can be said to be successful. By applying the learning method students are very quite have good enthusiasm when asked to go to the front the class tells about a pleasant experience or that memorable that was experienced by the students. Students are very happy because students are given good appreciation by Teacher who taught in the class despite several obstacle Sstudents in conveying stories such as a word selection and pronunciation of words. 
However, the Teacher motivation to teach is able to make students speak or telling story well.

\section{CONCLUSION}

Based on the results and discussion, it can be concluded that the use of methods telling stories with Recount Text or past experience can improve the speaking skills, as well as improve better activity for students.

\section{REFERENCES}

Alexander, L.,G. (1975). Practical and progress. London: Longman. , in partial fulfillment of the requirements for the degree of Sarjana Pendidikan in English.

Brown, H. D. (2004). Language Assement: Principles and Classroom Practices. New York: Longman, in partial fulfillment of the requirements for the degree of Sarjana Pendidikan in English.

Chen \& I-Jung. (2005). using games to promote communicative skills in language learning. In internet TESL Journal, 12(2)

Kurnia,. (2015). Improving Students Spoken Recount Skill Through Fishbowl Technique. in partial fulfillment of the requirements for degree of Sarjana Pendidikan.

Malinda. (2017). improving students writing ability in recount text using picture series. Jurnal Repository UIN Sumatera Utara, 52(2).

Tarigan, \& Guntur, H. (2008). Berbicara sebagai Keterampilan Berbahasa. Bandung : angkasa, Jurnal Repository UIN Sumatera Utara,52(2)

Ultaminingsih, M. N. (2012). Im;proving Students Speaking Ability Through Story Board. Final Project English Department FBS Unnes. Unpublished. 